Law Eु Social Inquiry

Volume 44, Issue 1, 58-77, February 2019

\title{
A Grassroots History of Colorblind Conservative Constitutionalism
}

Ariela Gross

In this article, I argue that colorblind conservative constitutionalism has its roots not only in Supreme Court jurisprudence and the machinations of national political actors, but also in the deliberate campaigns of opponents of integration at the grassroots. On the local level, resistance to integration was not confined to the South. I offer a case study of grassroots activism in Los Angeles, where white citizens opposed black efforts to integrate schools and housing using the language of freedom of association and freedom of choice. Although this language originated in race-conscious political action, it became the basis for race-neutral opposition to big government and taxes, and support for "school choice." Formal colorblind conservatism in the courts did not legally ratify changes that happened naturally, socially, through individual actions; on the contrary, grassroots conservatives consciously pursued legal strategies to fight integration from the ground up as well as from the top down.

\section{INTRODUCTION}

One of the most famous lines in US constitutional history comes from Justice Harlan's dissent in Plessy v. Ferguson: "Our Constitution is color-blind" (1896, 559). In the now-familiar narrative of Supreme Court equal protection jurisprudence, Harlan's "color-blindness" was a powerful tool in the hands of racial liberals at midtwentieth century, wielded to strike down statutes mandating racial segregation as well as judicial enforcement of racially restrictive housing covenants and a host of other forms of discrimination (Shelley v. Kraemer 1948; Brown v. Board of Education 1954; Hernandez v. Texas 1954). Yet in the 1970s and 1980s, conservative judges began to invoke the colorblind constitution to invalidate programs to redress racial injustice through law to protect white plaintiffs from any form of racial classification (Schmidt 2008, 236; Chemerinsky 2010, 60-61). By the 1990s, the US Supreme Court had adopted "colorblind conservatism" as its reigning ideology. In majority opinions in

Ariela J. Gross is the John B. \& Alice R. Sharp Professor of Law \& History, USC Gould School of Law and may be contacted at agross@law.usc.edu. The author thanks Catherine Albiston, Scott Altman, Steve Andrews, Leora Bilsky, Mark Brilliant, Kevin Brown, Tomiko Brown-Nagin, Alex Capron, Devon Carbado, Justin Driver, Mary Dudziak, Eric Fassin, Ron Garet, Risa Goluboff, Bob Gordon, Mike Greenberg, Ian Haney Lopez, Laura Kalman, Hila Keren, Jeremy Kessler, Jay Krishnan, Liora Israel, Roy Kreitner, Sophia Z. Lee, Kenneth Mack, Nancy MacLean, James May, Melissa Murray, Pap Ndiaye, Daria Roithmayr, Logan Sawyer, Reuel Schiller, Christopher Schmidt, Nomi Stolzenberg, Tom Sugrue, Leti Volpp, Anders Walker, William Wiecek, participants in meetings of the American Society for Legal History and the Law and Society Association, and faculty workshops at the École des Hautes Études en Sciences Sociales, the UC Berkeley Center for the Study of Law and Society, the Southwestern Law School, Duke Law School, Indiana University School of Law, and the Tel Aviv University Law Faculty for comments on the article and conversations about the grassroots history of the civil rights era and colorblind conservatism. 
successive cases regarding affirmative action in education and employment, the Court extolled race neutrality as the dominant value in equality jurisprudence. ${ }^{1}$

Scholars have linked this Supreme Court-centered narrative to a history of national electoral politics in which the rise of the civil rights movement set off a chain of events leading to the rise of the Right - a "chain reaction," in the words of Thomas and Mary Edsall (1992). According to this story, violent, massive resistance in the South to the integration of schools and other public spaces triggered a national response in favor of federal civil rights enforcement (Bartley 1999; Chalmers 2003; Klarman 2004; Webb 2005). The passage of the Civil Rights Act and the Voting Rights Act, in turn, generated a successful Republican "southern strategy" to pry white working-class voters away from the Democratic Party using race as a "wedge" (Phillips 1969; Murphy and Gulliver, 1971; Edsall and Edsall 1992, 43). This led to the "Southernization" of US politics (Egerton 1974, 128-30). The move from civil rights to colorblindness, especially as associated with New Right political figures such as Norman Podhoretz and Nathan Glazer, epitomized the end of 1960s liberalism, the marginalization of the radical Left and Black Power, and a national mood of "racial exhaustion" (Hutchinson 2009). ${ }^{2}$

These narratives capture important truths, but they are incomplete. In this article, I argue that colorblind conservative constitutionalism has its roots not only in Supreme Court jurisprudence and the machinations of national political actors, but also in the deliberate campaigns of opponents of integration at the grassroots. ${ }^{3}$ Furthermore, these contests took place not only in the South, but also across the country, including in the West. I examine two political battles that galvanized conservatives in Los Angeles: first, the fight to overturn fair housing legislation through a ballot initiative in 1964; and second, the campaign, from the 1960s through the early 1980s, against desegregation of the city's public schools. As my case study of grassroots activism in Los Angeles demonstrates, on the local level, white citizens in Los Angeles, like those in Atlanta or Jackson, resisted black efforts to integrate schools and housing using the language of freedom of association and freedom of choice. Although this language originated in race-conscious political action, it became the basis for race-neutral opposition to big government and taxes, and support for "school choice." Formal colorblind conservatism in the courts did not legally ratify changes that happened naturally, socially, through individual actions; on the contrary, grassroots political actors consciously pursued legal strategies to fight integration from the ground up as well as from the top down.

1. Critical race theorists have ably and exhaustively illuminated this development. Two of the most illuminating treatments are Neil Gotanda (1999) and Ian F. Haney López (2007). The longer history of the concept of the colorblind constitution has been well told by Kull (1992).

2. Dan T. Carter $(1995,347-50 ; 1996,28-40)$ traces the cause of this shift to economic factors as the 1950s boom ended and more pressure came to bear on the working class, putting economic concerns over racial ones for many poor whites; Thomas and Mary Edsall (1992, 47-98) identify forces that began to fracture the civil rights coalition during the 1960s, including the inability to prevent riots, which ultimately led many Americans to shift to a more conservative outlook and ultimately paved the way for Richard Nixon's 1968 presidential victory. For a critique of the Edsalls' influential backlash thesis, see Lowndes (2008).

3. My definition of "grassroots" encompasses not only suburban parents who wrote to judges and legislators, but also movement lawyers and associations at the local and state level, such as the California Real Estate Association (CREA), that spearheaded litigation and ballot initiatives. 
At the ground level, massive resistance is only part of the story. My study of grassroots mobilization against racial integration in Los Angeles builds on the work of a new generation of political and social historians who have revised the topdown "southern strategy" story in critical ways. Their research has illuminated the popular constitutionalism of opponents of integration, through studies of the suburban South as well as the urban North (Kruse 2005; Lassiter 2006; Crespino 2007; Freund 2007; Sugrue 2008; Lands 2009; Sokol 2014). White residents' nonviolent and legal defense of their prerogatives drew on the legacy of a "politics of 'strategic accommodation' and coded conservatism" that predated Brown v. Board of Education (Ward 2011, 6). The shift to colorblind ideology was not imposed from above, but developed among the "Silent Majority" in local battles in which people identified less by political party than "as homeowners, taxpayers, and schoolparents" (Lassiter 2006, 7). Furthermore, "[c]onservative color blindness ... [was] not the invention of Republican presidential political strategists or of white suburbanites," but grew out of a longer tradition of segregationist politics and colorblind "states' rights" arguments (Lassiter 2010, 44). This grassroots political history has begun to inform new legal historical research on the popular constitutionalism of the Right (Siegel 2008; Southworth 2008; Teles 2009; Walker 2009; Schmidt 2011; Driver 2014) that presents a mirror image to recent grassroots legal histories of the civil rights movement (Mack 2005, 2012; Goluboff 2007; Schmidt 2010, 2015; Brown-Nagin 2011). This case study is an attempt to make the connections between local anti-civil rights politics and the legal and constitutional history of race more explicit.

Local battles over formerly white neighborhoods and public spaces were happening not only in the South, but also in the North and West (Carter 1995; Sugrue 2004; Schulman 2008; Crespino 2010; Kruse 2010; MacLean 2010; Theoharis 2010). My analysis of the development of colorblind conservatism in Los Angeles also builds on recent scholarship that has enriched our understanding of the mobilization of conservatives beyond the South. Southern California was ground zero for the rise of evangelical conservatism in the 1960s, fueled in part by migrants from the South who brought with them racial and religious attitudes identified with the South (Dochuk 2011; Didion 2017). Many of the "housewife activists" holding coffee klatches for Barry Goldwater became foot soldiers in the movement against the integration they saw threatening them in 1963 and 1964 (Nickerson 2012, xiv-xv; McGirr 2001; Nicolaides 2002; Williams 2010; Barraclough 2011; Dochuk 2011).

A closer examination of Los Angeles in the civil rights era shows how these grassroots conservatives learned to couch their opposition to integration in terms of individual freedom of choice, including the freedom to choose one's neighbors, and to choose religious schools with public tuition grants. They merged the issues of religious-school tax exemptions with opposition to taxation for the provision of public goods (such as parks and swimming pools) that were once whites-only. In the battle against desegregation of schools, these arguments were taken up by many who did not identify as conservatives. They appealed to a much broader swath of Democrats as well as Republicans, making once-conservative positions mainstream and entrenching racial privilege in seemingly neutral language (Self 2003; HoSang 2008). My case study pinpoints when certain kinds of arguments against integration lost their force (e.g., the inferiority of some racial or cultural groups, or the right to 
discriminate) and others gained momentum (the right to choose, the need for smaller government). ${ }^{4}$ In the 1950s-1970s, arguments against big government and taxation gained urgency from their power as race-neutral rights claims against racial integration: legal rights claims that could stand up to civil rights claims. ${ }^{5}$ Grassroots conservatives in Los Angeles played a key role in shaping the colorblind constitutionalism that dominates race jurisprudence in our courts today.

\section{FREEDOM OF CHOICE VERSUS "FORCED HOUSING" IN LOS ANGELES}

In 1954, when the US Supreme Court decided Brown v. Board of Education, Los Angeles was already well on its way to having one of the most segregated school systems in the United States. Despite the landmark Ninth Circuit decision in Westminster School District v. Mendez (1947, 780-81), declaring that Mexican Americans could not be relegated to separate schools according to the California school segregation statute, Los Angeles and Orange County school districts used annexation and secession to gerrymander whites and "Mexicans" into separate school systems. For example, in the area that was litigated in the Mendez case, an all-Anglo section of the El Modena School District transferred into the all-white Tustin School District in the fall of 1947, and six years later, a number of school districts in Orange County were unified, diluting Mexican American political power (Gross 2007, 384). By the mid-1960s, when civil rights activists began to push integration of the schools to the top of the political agenda, including busing children between districts, nearly half the schools in the Los Angeles Unified School District were classified as more than 50 percent minority ("black" or "Mexican").

Jim Crow lived outside the South, as did a vibrant civil rights movement-and an active movement of reaction and opposition to integration of African Americans and Mexican Americans into public institutions and neighborhood spaces. Residential segregation looked somewhat different in Los Angeles than in other parts of the country. Zoning, "redlining," and racially restrictive covenants kept African Americans concentrated into a four-square-mile portion of South Central Los Angeles just south of downtown (Sides 2003, 98). After World War II, with the

4. Some scholars have argued that this was the moment at which white political actors in California could join forces from across the political spectrum to oppose affirmative integration remedies precisely because mechanisms like the de facto/de jure distinction allowed them to distance themselves from racial injustice and characterize it as only a southern problem (Self 2003; HoSang 2008). For my purposes, it is less important to draw a sharp line between "conservatives" and "liberals" than to trace the rise of "colorblind" rhetoric in the service of opposition to integration and programs of redress for racial injustice. It may be true not only that the rise of constitutional colorblindness coincided with the growing power of the Right, but also that colorblindness could garner support across the ideological spectrum.

5. Although I focus here on the 1960s and 1970s, these were only two episodes in a longer struggle over civil rights that began during Reconstruction and has yet to end.

6. See Crawford v. Board of Education (1976) (summarizing the trial court's findings of fact that Los Angeles was one of the most segregated areas in the United States and including statistical data); US Commission on Civil Rights (1977) (summarizing further demographic studies, including a factual finding by the trial judge in Crawford that most of the district's schools were either 90 percent white or 90 percent minority students, as well as a 1971 US Department of Health, Welfare, and Education enrollment survey finding that 86.6 percent of black pupils in the area attended schools that were more than 80 percent black). 
pressure of the Great Migration, what had been multiethnic neighborhoods of blacks, Asians, Mexicans, Italians, and Jews became more solidly African American enclaves, as others moved out, but blacks remained shut out of surrounding areas. A report by the Los Angeles Commission on Human Relations found that "in the ten-year period ending in April 1960, only 1,437 additional Negro citizens, or 0.87 percent, have found residences outside of the Central District of Los Angeles, and in San Pedro, Venice and Pacoima" (Sanchez n.d., 26). An even more important change, however, was the willingness of African Americans to demand the right to live in formerly white neighborhoods, and to fight racial exclusion in the courts and on the streets (Sides 2003, 98-101).

White homeowners reacted to African Americans' new legal assertiveness in a variety of ways. The Los Angeles Urban League "identified no fewer than twentysix techniques used by white homeowners to exclude blacks," everything from payoffs to neighbors to keep them from selling to African Americans, to death threats and violence against black buyers (Sides 2003, 101). Although cross burnings and bombings certainly occurred, the most effective opponents of integration were nonviolent - and even race neutral — in their resistance. The conservative activists who organized in reaction to desegregation claimed rights for white people, but they did so in terms that were rarely explicitly racial.

In Los Angeles, the leading organization opposing CORE and NAACP's integration campaign was known as the Taxpayers Rebellion of California, formed in mid-1963 by Mary Frisina, a resident of Huntington Park. ${ }^{7}$ The Taxpayers Rebellion, which grew to one hundred groups in twenty-two counties within a few months in late 1963, demanded tax cuts by equating government spending with integration, special privileges for minorities, and welfare programs that would support blacks and Mexican Americans at whites' expense. In January 1964, Frisina's group organized "Women on the War Path," a downtown protest of the Los Angeles County Board of Supervisors (Nicolaides 2002, 302-03). As Camille Walsh (2011, forthcoming) has argued, whites in the North as well as in the South claimed the right to education and other public goods in battles over segregation in terms of their taxpayer status; both whites and African Americans framed their legal claims as taxpayer citizens.

The newspapers in 1964-1967 were filled with stories about taxpayer rebellions. As the Los Angeles Times chronicled, "a taxpayer rebellion spread through Southern California as winter turned to spring this school year of 1966-67. It was against the schools the blow fell." Schools laid off teachers, and cut athletics and other programs. The newspaper noted that "in the 1950s 70\% of tax and bond elections for Southern California schools were approved by the voters. In 1965 the success rate was down to 55\%" (Torgerson 1967). The main thing that had changed was the specter of desegregation. As Assemblyman Floyd Wakefield noted a few years later, "The people of California have lost faith in their educational system. All we have to do is look at the record of school bonds being defeated in this state. In Los Angeles alone, the bond issue was defeated three times consecutively. And I

7. On CORE's campaign, see "Sit-In for Fair Housing Starts in State Capitol," Los Angeles Times, May 30, 1963, 2; "Sit-Ins at Sacramento Reinforced from L.A.," Los Angeles Times, June 2, 1963, GA. 
believe it boils down to the fact that people are tired of paying for unnecessary programs and expensive buses to soothe a minority of social reformers." ${ }^{8}$

At the very same time taxpayers were rebelling in Los Angeles, a major campaign was underway to fight fair housing legislation. The Rumford Fair Housing Act had been passed in June 1963, in a climate of increasing civil rights activism. CORE held protests daily in the California Senate rotunda in the month leading up to the passage of the bill. ${ }^{9}$ The California Real Estate Association drafted Proposition 14, placed on the ballot in November 1963, to do more than overturn the Rumford Act. Proposition 14 was an initiative that placed in the constitution broad rights to discriminate. ${ }^{10}$

CREA framed the proposition in terms of rights and choice: "Neither the State nor any subdivision or agency thereof shall deny, limit, or abridge, directly or indirectly, the right of any person, who is willing or desires to sell, lease, or rent any part or all of his real property, to decline to sell, lease or rent such property to such person or persons as he, in his absolute discretion, chooses." As ACLU lawyer Fred Okrand noted, "This was neutral language.... It sounds perfectly American. But of course, the reason for that was to allow persons to have the right to discriminate" (Online Archive of California 1984, 422-23). The proponents of Proposition 14 argued that the Rumford "Forced Housing Act" took away property owners' "freedom of choice."11 As the CREA Committee for Home Protection warned, "The politically appointed [Housing] Commission can FORCE you to sell or rent your home to an individual NOT OF YOUR CHOICE" (HoSang 2010, 65). They asked, rhetorically: "But doesn't Freedom of Choice involve discrimination? If so, isn't discrimination the same as segregation? No, discrimination means simply that a person makes a choice." A CREA poster urged that a "Yes Vote will restore to California property owners the right to choose the person or persons to whom they wish to sell or rent ... will abolish those provisions of the Rumford Forced Housing Act of 1963 which took from Californians their freedom of choice ... will restore rights basic to our freedom." Proponents also argued that property rights were no less important than human rights, indeed that "a man without property rights-

8. "Urge Rights of Students to Attend Nearest School," unnamed newspaper, November 4, 1971, 14B, Box 17, F. 1, Bustop Campaign Collection, California State University at Northridge, Urban Archives Center.

9. "The Story of the 1963 Civil Rights Legislation," Graduate Theological Union Archives, Berkeley, California, Proposition 14 Materials.

10. The test case for Proposition 14 was a referendum overturning Berkeley's fair housing ordinance; in April 1963, with 82 percent turnout, Berkeley voters passed a referendum similar to Proposition 14. Because the vote was close $(22,720$ to 20,323$)$, fair housing proponents remained confident of their chances. See "The Story of the 1963 Legislature," http://www.fclca.org/images/stories/pdfs/fclca_1963_report.pdf.

11. See, for example, "Why You Should Vote Yes on Proposition 14," William Steuart McBirnie, Senior Minister, United Community Church, Glendale, California, in Radical Right Collection, Box 4, Hoover Institution Archives, Stanford University; "Forced Housing vs. Freedom of Choice," by Reg F. Dupuy, Long Beach, California, in Radical Right Collection, Box 38, Hoover Institution Archives, Stanford University; "Why 'Yes' on Proposition \#14?" in Radical Right Collection, Box 4, Hoover Institution Archives, Stanford University; "Here's Why We Must Vote Yes on Proposition 14," Carton 7, F. 7, Rumford Papers, Bancroft Library Archives and Special Collections, UC Berkeley; "The Property Owner's Bill of Rights," Proposition 14 Materials, Max Mont Collection, California State University at Northridge, Urban Archives Center. 
without the right to the product of his own labor-is not a free man." ${ }^{12}$ As Daniel Martinez HoSang $(2010,66)$ argues, "Proposition 14 supporters steeped their arguments in the rhetoric of egalitarianism and even antiracism. Incorporating dimensions of emergent liberal civil rights discourse, they portrayed racial discrimination as a regretful but individually rooted problem of morality and tolerance, one the state could or should do little to address." Proposition 14 supporters also used the rhetoric of big versus small government: according to CREA, "Your yes vote will require the state to remain neutral," and would be a blow to the "tyranny" of government "bureaucrats." approach" to government. ${ }^{14}$

The "free-choicers" argued that residential segregation was a matter of individual choice, just as they did in Atlanta and Chicago, despite the fact that black and Mexican ghettos and whites-only suburbs had been built through decades of federal Home Owners Loan Corporation (HOLC) policies making "racial distinctions a central determinant in appraising a neighborhood's suitability for federally backed loans," and the Federal Housing Administration's adoption of HOLC's rating system for mortgage guarantees as well as model racial covenants in their standard agreements for builders (HoSang 2010, 145; Freund 2007; Satter 2010).

Charles Shattuck, the past president of CREA, testifying before the California Assembly Interim Committee on Governmental Efficiency and Economy, freely admitted that the Los Angeles Real Estate Board refused to admit black realtors, hence effectively excluding them from selling property to African Americans in large swaths of the city. Shattuck refused to characterize this as "segregation." "That was their position, that it was segregation," he explained. "But it was our position that they are primarily dealing with the Negro race," so they should be limited to "those portions of the City that are of that character... We are not going to be a party to the salt and peppering of the whole community." When asked what he meant by "salt and peppering," he explained that it was simply a matter of "birds of a feather flock together" and had nothing to do with property values; whites just did not want to live near blacks. Yet when asked directly whether he believed that a person should have the same right to own property or live in any section of the city based on color, Shattuck replied: "They have that today. They have that same right today." 15 Despite this frank acknowledgment of exclusion, opponents of desegregation continued to talk about racial patterns as natural and not created by deliberate policy. This "national myth" of "de facto" segregation in the North and West

12. Dupuy, Reg F. "Forced Housing vs. Freedom of Choice," Long Beach, California, in Radical Right Collection, Box 38, Hoover Institution Archives, Stanford University, 1-2.

13. Text of CREA's ballot argument for the constitutional amendment, YES on 14, June 27, 14, GTU Archives, Proposition 14 materials.

14. Freedom of Choice vs. Forced Housing, GTU Archives. Some proponents went even farther, calling the Rumford Act a "Nazi-type, Commie-type law ... that Destroys Freedom of Choice for All Americans" (A Man's Home Is His Castle! Rumford Papers, Bancroft Library, UC Berkeley, 7:7).

15. Assembly Interim Committee on Governmental Efficiency and Economy, Hearing in Los Angeles, September 28-29, 1961, Testimony of Mr. Charles Shattuck, 50, in CREA materials, Max Mont Collection, Box 2, Folder 16, California State University at Northridge, Oviatt Library, Special Collections and Archives. 
being something entirely different from de jure segregation in the South remains strong in our historical tradition even today. ${ }^{16}$

Although a wide array of civic groups, politicians, and religious figures supported fair housing, there were also strong mainstream supporters of Proposition 14, including the Los Angeles Times (Felter-Kantor 2013). In a February 2, 1964 editorial, the Times explained that it had "pondered the issue for weeks," but concluded: "One of man's most ancient rights in a free society is the privilege of using and disposing of his private property in whatever manner he deems appropriate." Although the Times looked forward to a time when minorities would have "the privilege of living wherever one's economic means permit," the editorial board believed that "artificial laws designed to hasten the process of social, as distinct from civil, justice can only exacerbate the situation," and would "correct ... a social evil while simultaneously destroying what we deem a basic right in a free society," the right to discriminate in the sale of real estate (Los Angeles Times 1964, K6).

California voters overwhelmingly approved Proposition 14, by a vote of nearly two to one. While the media reported that the proposition drew its support mainly from "laboring-class people who fear, rightly or wrongly, that their property would be devaluated by the presence of Negroes in the neighborhood" (Time Magazine 1964), recent studies suggest that the class base for opposition to open housing was broad (Self 2003). ${ }^{17}$ Although the California Supreme Court overturned the ballot referendum the following year, and the US Supreme Court upheld that decision in 1966, Justice John M. Harlan's dissenting opinion in the 5-4 decision echoed conservative arguments about freedom of choice and race neutrality, calling the proposition "neutral" and "inoffensive on its face" (Reitman v. Mulkey 1967; Time Magazine 1967). The petitioners' briefs to the Supreme Court emphasized "the freedom of a residential property owner to select the person with whom he will or will not deal," and the "long-cherished rights of privacy and freedom of association and established and valued though admittedly not absolute rights to own, enjoy and dispose of property." ${ }^{18}$ The petitioners were represented by the top law firm, Gibson, Dunn and Crutcher, and financed by CREA. ${ }^{19}$ Furthermore, Governor Ronald Reagan told the California Real Estate Association in 1967 that he would reopen efforts to repeal the open housing law, or seek amendments to make it "no longer discriminatory and oppressive" (Bergholz 1967, 8).

16. Lassiter $(2010,25)$ traces the development of the de jure/de facto distinction from its origin as a NAACP strategy to appeal to the consciences of policymakers to the ultimate, unintended result of insulating many segregated northern communities from liability.

17. Robert Self $(2003,168)$ stated that "[t]he numbers suggest that the resistance to desegregation in Oakland did not come solely from an antiliberal white working class engaged in direct struggle with African Americans over jobs and housing, but arose equally among middle-and upper-class whites who understood property rights as sacrosanct expressions of their personal freedom and had little daily contact with African Americans"; see also Time Magazine (1964).

18. Reply Brief for Petitioners, Reitman v. Mulkey, 25, 42.

19. Okrand noted that "in those days it was wrong for lawyers to advertise or to go out and get cases ... But Sam[uel O. Pruitt, Jr., senior partner at Gibson, Dunn] confessed to us that they had done a little bit of ambulance chasing ... the California [Real Estate] Association had gone out and offered legal services to all of the parties" (Online Archive of California 1984, 426). 


\section{FROM "FORCED HOUSING” TO "FORCED BUSING"}

At the same time that Californians were mobilizing to combat integration in housing, some were arguing in the context of school integration that any residential segregation that existed in Los Angeles was entirely natural and unplanned, the result of black migration to the central city in the aftermath of World War II. The first lawsuit to challenge segregated schools was filed in Pasadena, an old, wealthy suburb north of the city that had only a small population of blacks and Mexican Americans. As early as 1951, a new superintendent of schools, Willard Goslin, had tried to open several new schools and abolish reverse busing of white students from integrated neighborhoods to white schools. According to a contemporaneous account, white residents "wished to register the strongest kind of objection to sending their teenagers to Washington Junior High School, even though it was much nearer home, instead of to La Cañada, which, although it was across the Arroyo, had a privileged class of pupils.... What they did not say in so many words, but what was perfectly plain, was that they were afraid ... property values would decline because children in the affected neighborhoods would have to attend classes with Negro and Mexican children" (Hulburd 1951, 71, 93, 98). The opponents of integration succeeded not only in pushing out the superintendent, but also in voting down an increase in school taxes for the first time in Pasadena history, by a margin of more than two to one. According to Michelle Nickerson (2012, xix), the "Pasadena affair" was the first occasion in which women conservative activists "asserted themselves effectively in postwar Southern California politics."

In 1961, Jay Jackson, a thirteen-year-old black boy, sued the Pasadena School District when he was not allowed to transfer from Washington Junior High School, a predominantly black school, to Eliot, a predominantly white school. As Fred Okrand of the ACLU put it, "Pasadena had an intentionally segregated school system.... [B]lacks were transported past white schools in the typical old Southern fashion" (Online Archive of California 1984, 450-51). The California Supreme Court ruled that Pasadena had gerrymandered school boundaries and that Washington was "inherently inferior," but the court went further. Dismissing the significance of the de jure/de facto distinction, the California court suggested that a student could obtain judicial relief "even in the absence of gerrymandering or other affirmative discrimination" because "residential segregation is itself an evil," and "[w]here such segregation exists ... [th] e right to an equal opportunity for education and the harmful consequences of segregation require that school boards take steps, insofar as reasonably feasible, to alleviate racial imbalance in schools regardless of its cause" (Jackson v. Pasadena 1963, 880). This statement, that even "de facto" segregation might require a state response, went beyond anything the US Supreme Court had held, and it was decided under the California Constitution. Those words paved the way for a case to be brought against the much larger Los Angeles Unified School District, Crawford v. Board of Education, in 1963, over the segregation of Jordan High School. As Okrand explained: "That's what was the genesis of Crawford. That dictum. That so-called dictum" (Online Archive of California 1984, 452). Elnora Crowder, an African American teacher and activist, went door to door in Watts to 
find Mary Ellen Crawford and Inita Watkins, Jordan High students, to be plaintiffs in the case (Nicolaides 2002, 291).

It took four years from the filing of the Crawford case to the actual trial in 1967. Okrand recalled that the Los Angeles Board of Education made "one excuse after another" not to desegregate Jordan High, with the South Gate neighborhood mobilizing in "rallies and meetings" (Online Archive of California 1984, 456). Later, Okrand remembered: "As I look back, I wonder at our temperance and at our patience, if that's the description, because it wasn't until about almost five years later that we decided that we've had enough of this" (Online Archive of California 1984, 456). During those volatile years, the black neighborhood of Watts exploded in riots, and the commission that considered its causes concluded that "the economic conditions and atmosphere reflected the fear and apprehension of school integration in Los Angeles." As Paul Egly, the judge who took over the Crawford case much later, argued: "The violence of the riots likely exacerbated the LAUSD's resistance to desegregation" (Egly 2010, 271-72). ${ }^{20}$

In the years before Crawford went to trial, white resisters to integration mobilized. In the white working-class suburbs of Huntington Park and South Gate, Mary Frisina and others organized at school board meetings. Countering 750 hymnsinging demonstrators in favor of integration, board of education member Charles Reed Smoot opposed integration "on legal grounds": "We cannot depart from the principle of equality in our school system.... We cannot exclude children from their neighborhood schools because of their race, nor can we compel their attendance at more distant schools on account of their race." Frisina, the leader of the Taxpayers Rebellion, read into the board of education record a letter she claimed was written by a "Negro teacher" criticizing the NAACP, and a Mrs. MacFarlane urged the board that "white people have rights too." ${ }^{21}$ In school board meetings, "Frisina articulated a new anti-tax ideology_often in caustic terms-that racialized the nature of public spending: no public money should be spent on programs to promote integration, give special privilege to minorities, or otherwise drain the pockets of white taxpayers for programs that would not help them" (Nicolaides 2002, 302).

Two San Fernando Valley women, Bobbie Fiedler and Roberta Weintraub, helped to form Bustop, an organization that sought at all costs to prevent busing for the purposes of integration. Bustop never fomented the kind of violence that met integration in Little Rock or in Boston. However, as the ACLU Foundation Legal Director had argued before the US Supreme Court in another case involving Pasadena schools: "You don't have to break windows and overturn buses to have resistance" (Redlands Daily Facts 1976). Bustop focused on both the rights of parents to choose, and the problem of "white flight," which it characterized as an inevitable reaction to mandatory desegregation plans, rather than a product, at least in part, of ongoing discriminatory government policies, which could be reversed. It also very successfully tied opposition to integration to the tax rebellion. As one

20. See also McCone Commission. Violence in the City: An End or a Beginning? 1965. https://archive.org/details/ViolenceInCity.

21. Leslie E. Claypool, "Sparks Fly at School Integration Meeting," July 23, 1963; "Thorny Racial Question Confronts School Board,” July 26, 1963, in Egly Collection, Archives and Special Collections, UCLA. 
letter-writer to Judge Egly wrote, "Turn this case around and give us back our individual freedom of choice! Remember 'taxation without representation'-200 years ago-well, this is where we are in the school desegregation case. We are asked to relinquish our children's right to attend their neighborhood school, yet we pay for these schools through our taxes." 22

Recalling her campaign twenty years later, Bobbi Fiedler explained that she vigorously opposed "deliberate segregation" because she was Jewish and remembered the history of Japanese internment as well as the Holocaust, but she also "strongly oppos[ed] mandatory integration." 23 The group first formed in 1966 to fight the "Racial-Ethnic Survey" that sought to take a demographic snapshot of the Los Angeles schools because until that point there were no statistics about how many white, black, or Mexican students were in the school system. The women who formed Bustop opposed "individually identify[ing] and classify[ing] each student ... based on [his or her] race and ethnicity." Fiedler explained the arguments against desegregation in terms of freedom of choice: "[W]hatever level of integration or lack of it took place" in Los Angeles "was a result of free choice of the people who lived there." Furthermore, "the cost of the desegregation effort ... is just tremendous proportional to the overall cost of the educational program." At its peak, Bustop had as many as thirty thousand active members attending meetings, and the group successfully intervened in the Crawford litigation as it proceeded on appeal throughout the 1970s. Bobbi Fiedler went on to run successfully for the Los Angeles Board of Education, and her soon-to-be husband, Paul Crock, took over leadership of Bustop. ${ }^{24}$

A central focus of the trial in 1969 and 1970 was the question of de jure versus de facto segregation. If the Los Angeles Board of Education had known that its decisions and choices would not remedy segregation and would in fact perpetuate it, were its members acting in "bad faith"? Did "bad faith" mean that individual board members were "pro-segregation" or acting out of "animus"? In colloquies between Judge Gitelson and lawyers for the plaintiffs and for the school board, the judge repeatedly tried to clarify what the parties meant. Judge Gitelson suggested to the ACLU lawyer for the plaintiffs, Bayard Berman, that he saw the school board as having a duty of good faith "like the trustee's duty to a beneficiary" so that the "failure to exercise the highest degree of honesty is bad faith." ${ }^{25}$ Berman replied: "Obviously we don't charge the extreme kind of bad faith evidenced in the cases which deal with classic forms of de jure segregation; that is to say, that the Board followed a course of action, explicit or implicit, which prohibited minority students from moving into areas where they could go to schools with pupils of the majority groups.... We don't contend that there was [sic] collectively or individually any feelings of personal animus toward members of the minority groups." Berman did argue, however, that there was "evidence of ... perpetuating, of knowingly and

22. “Mrs. C. Goldstein to Paul Egly,” Egly Collection, Archives and Special Collections, UCLA.

23. "Oral History Interview with Bobbi Fiedler," November 17, 1988, California State University at Northridge, Urban Archives Center.

24. Ibid.

25. Crawford v. LAUSD Files, California State Archives [CSA], Trial Transcript, 1969, Vol. 54, $11121-24$. 
intentionally perpetuating this kind of a system." Berman concluded by saying, "I think that for political, for staff, for considerations of structure, that is, the bureaucracy itself, for community considerations, the Board of Education, since Brown, has followed the path of least resistance knowingly, and has knowingly maintained a biracial system of education, and I charge that as bad faith beyond stupidity." At that point, Judge Gitelson urged Berman to analogize this type of bad faith to "constructive fraud" as opposed to "express intent to defraud." ${ }^{26}$ Following this discussion, Superintendent of Schools Daniel Kelly testified, urging that any segregation in Los Angeles was merely "de facto," because "de jure segregation ... is segregation which is mandated through the force of law." De facto segregation, he argued, was "segregation which takes place because of many circumstances involving, to a certain extent, I suppose, the element of choice on the part of the individual, but not entirely." 27

These competing understandings of de jure and de facto segregation were at the heart of this case. Did "de jure" segregation encompass only statutorily enforced separation, or did it also include any segregation that resulted from deliberate state action, or even an accumulation of small (intentional but not hate-inspired) actions that together resulted in segregation? In 1970, Judge Gitelson issued his findings of fact and conclusions of law in the Crawford case. Although, following Jackson v. Pasadena, he concluded that the board of education had a duty to desegregate, whatever the cause of segregation, Judge Gitelson found as a matter of fact that segregation in Los Angeles was de jure, that is, that the school board had "knowingly, affirmatively, and in bad faith ... by and through its actual affirmative policies, customs, usages, and practices, doings and omissions, segregated, de jure, its students." Among the affirmative acts Gitelson found were school siting decisions, boundary maintenance, transportation policies, and transfer policies that created and perpetuated segregation. ${ }^{28}$ As John Caughey noted later in an amicus brief, Judge Gitelson "included more than forty acts of bad faith by the Board of Education, many of them multiple and all in the short span of 1963-68... Bad faith continued throughout the period of appeal, one instance being the pleading of agnosticism on the charge of genetic inferiority of Negroes, which, if correct, might make desegregation futile." 29 As Judge Gitelson explained afterward in an interview: "De jure segregation is any segregation either caused, or affirmatively perpetuated, or affirmatively caused to continue, by an affirmed act of the governing school board.... De facto could only exist where you had an area which was in fact static ... given any area which continues to grow, where a school or schools may be segregated and where you create new schools knowing or intending that they should be segregated, you have affirmative [de jure] action."30 Thus, Judge Gitelson's findings of fact,

26. Ibid., Vol. 54, 11131-33.

27. Ibid., Vol. 55, 12038. See also Vol. 58, Berman discussion of "de jure" and "de facto."

28. Judge Gitelson. 1970. Findings of Fact and Conclusions of Law. IV. 36, 24; available at Egly Collection, Special Collections and Archives, UCLA.

29. John Caughey Amicus Brief re Recalcitrance, 2, available in Egly Collection, Special Collections and Archives, UCLA.

30. "Interview with Judge Alfred Gitelson by KABC Communicator Mary Gray," March 20, 1970, available at Egly Collection, Special Collections and Archives, UCLA. 
using an expansive definition of de jure segregation, concluded that the Los Angeles School District was de jure segregated. Ironically, because he also in passing acknowledged that there could be a remedy even for de facto segregated schools, this finding was all but ignored in the later life of the Crawford case.

Following Judge Gitelson's order, the appeal "sat with the Second Division of the Court of Appeals for five years without decision" (Egly 2010, 274). Judge Egly (2010) later wrote that he was "unaware of the reasons it took so long, but I believe the appellate division hoped the US Supreme Court would eventually overrule Jackson" (2010, 274). Fred Okrand attributed the delay to the voluminous record and the years of briefing by numerous intervenors, as well as the hope that the US Supreme Court might settle some of the issues regarding desegregation (Online Archive of California 1984, 466-67). By the time the California Supreme Court decided the appeal, the case had become a focal point for staged battles over "forced busing." Opponents of desegregation, including Bustop and the board of education itself, filed briefs in support of the board's plans for token integration, and against Judge Gitelson's finding of de jure segregation.

The California Supreme Court ruled in 1976 that the Los Angeles Unified School District was in fact intentionally segregated. Yet, in what would turn out to be a tragic choice, the California court went on to explain that "we do not rest our decision on this characterization [of the segregation as de jure] because we continue to adhere to our conclusion in Jackson that school boards in California bear a constitutional obligation to take reasonably feasible steps to alleviate school segregation 'regardless of its cause"' (Crawford v. Board of Education 1976). By basing its ruling not on Los Angeles' de jure segregation, but on the conclusion that California's constitution required desegregation whether the initial harm was de facto or de jure, the court unwittingly paved the way for a state constitutional amendment.

The nail in the coffin of school integration in Los Angeles was the brainchild of a state senator, Alan Robbins, who formulated a ballot referendum, Proposition 1 , that would end "forced busing" by amending the California Constitution to "provide that nothing in [it] imposes ... any obligations or responsibilities which exceed those imposed by the United States Constitution with respect to the use of pupil school assignment or transportation." In other words, Proposition 1 struck down Jackson v. Pasadena's holding that equality of opportunity required desegregation whatever the cause of segregation. ${ }^{31}$

Robbins presented himself as a poor kid from an integrated neighborhood, "one of three Jewish kids in a mixed school of black, white, Mexican, and Asian students" who "faced prejudice-the hard way," and went South with

31. The full text of Proposition 1 read: "SCHOOL ASSIGNMENT AND TRANSPORTATION OF PUPILS. LEGISLATIVE CONSTITUTIONAL AMENDMENT. Amends Section 7(a) of Article I of the Constitution to provide that nothing in the California Constitution imposes upon the State of California or any public entity, board, or official any obligations or responsibilities which exceed those imposed by the United States Constitution with respect to the use of pupil school assignment or transportation. Provides for modification of existing judgments, decrees, writs or other court orders to conform to the provisions of this subdivision. Provides that governing boards of school districts may voluntarily continue or commence a school integration plan." http://repository.uchastings.edu/ca_ballot_props/861/ (accessed February 20, 2014). 
Martin Luther King Jr. to fight "for the right of little black children in Alabama to attend their neighborhood school." He framed Proposition 1 as the "CHOICE Initiative (Californians Helping to Obtain Individual Choices in Education)" that would allow Californians to "go back to loving our brothers without having a gun at our collective heads." 32 As Daniel Martinez HoSang has shown, Robbins presented himself as a racial liberal, garnered black and Chicano support for Proposition 1, and succeeded with "a discursive framework that incorporated, rather than rejected, the leading tenets of racial liberalism," not by abandoning appeals to "white rights," but by "recast[ing] 'white rights' through an assertion of 'racial innocence"” (2008, 288).

The Crawford petitioners, taken aback by this end run around the courts, filed briefs drawing the historic connection between the race-neutral opposition to "forced busing" of the Proposition 1 campaign and the race-neutral opposition to the "forced housing" of the Proposition 14 campaign sixteen years earlier, which had been overturned by the California Supreme Court. "It is not without significance," argued the petitioners' reply memo to Bustop's opening brief, "that in the material circulated by the CREA in support of Proposition 14 on the November 1964 ballot, the Association had a pamphlet entitled 'Freedom of Choice vs. Forced Housing.' ... At a press conference in Fresno on October 31, 1979, Senator Robbins was asked about his use of the phrase 'forced busing.' 'Isn't that a buzzword?' a reporter asked. 'Yes,' Senator Robbins replied, 'That's why we use it."' The petitioners concluded that Proposition 1 was "a culmination of California's historic discrimination against minorities." The lawyer for the Crawford petitioners, Fred Okrand of the ACLU, wrote to Alan Robbins in 1979, "to remind you of the fate of the similarly motivated 'neutral on its face' Proposition 14 on the 1964 California ballot," which was struck down "because it was clear that the State was putting its weight behind the private 'right' to discriminate in housing. The proposals now before the legislature seek to do the same thing as to schooling." 33 Judge Egly, in his recounting of the case, wrote that he had concluded "that racism was a basic premise and impetus to the success of Proposition 1. This conclusion seems true if we consider Bustop's position that the Caucasian population of the School District would move away" if desegregation were to occur. ${ }^{34}$

Of course, in the meantime, whites had been taking their children out of the Los Angeles school system. In 1966, the year of the first racial and ethnic survey, 56 percent of the children in the system were classified as Caucasian; by 1978, the proportion had fallen to 33 percent. The African American student population peaked in 1971, but it had fallen to 24 percent in 1978, with the Hispanic population doubling during the period 1966-1979 to 42 percent. Extensive school board hearings were held in 1978 and 1979 regarding "white flight." Numerous experts

32. Robbins speech, August 31, 1978, in Alan Robbins Collection, UCLA Special Collections. See also Correspondence, Alan Robbins Papers, California State Archives, Sacramento; Crawford materials, Southern California Library, Los Angeles, California, Integration Project Papers, Box 2.

33. "Letter from Fred Okrand to Senator," January 11, 1979, Exhibit E, available at Egly Collection, CLA Special Collections, at 1.

34. "Petitioners' Reply Memo to Bustop's Opening Brief," available at Egly Collection, UCLA Special Collections, at 304. 
testified on both sides, including black Harvard law professor Derrick Bell, on behalf of Bustop, to the effect that integration was not the best way to achieve opportunity for black students. ${ }^{35}$

Proposition 1 passed in November 1979 with 75 percent of the vote. Many who voted for it may not even have been aware that they were voting against integration, given the race-neutral language of the initiative. The Crawford litigation came to an end in 1981 after eighteen years, when the California Supreme Court refused to hear the case upholding the constitutionality of Proposition 1, and that decision was ratified by the US Supreme Court in 1982, with only Justice Marshall dissenting. Today, the Los Angeles Unified School District is one of the most segregated in the country, with few white children in the system. The campaign against "forced housing" laid the groundwork for the campaign against "forced busing," successfully defeating the last remnants of efforts to redress the segregation imposed by decades of discrimination in housing and education.

\section{CONCLUSION}

In the battle over Proposition 14, opponents of "forced housing" used the same "freedom of association" arguments that were a key part of southern litigation against the civil rights movement (Schmidt 2013). Although these arguments largely failed in their time, they are seeing a resurgence today, as opponents of same-sex marriage argue that they should have the right to discriminate against gay customers for wedding cakes, for example. These "freedom of association" arguments were not colorblind; they were clearly about the right to discriminate on the basis of race. The fight over "forced housing" was explicitly about the right of white people to choose white neighbors.

In the South, integration opponents mobilized "freedom of association" arguments against school desegregation as well. Clive Webb describes the Atlanta School Board's sympathetic acceptance of a white father's argument that his daughter's freedom of association rights should allow her to transfer to an all-white school (Webb 2005, 103). However, in Los Angeles, from the Proposition 14 battle to Crawford, "freedom of association" arguments transformed into race-neutral "freedom of choice" arguments. "Freedom of choice" was the slogan of choice in the Proposition 14 literature, and it was the same slogan that supported school vouchers and other race-neutral programs. This is important not only because anticivil rights activists learned to couch their claims as civil rights claims, or even because race-motivated actors adopted race-neutral terminology; it is also significant that the move to "colorblindness" emerged out of important strands in US politics at the grassroots as well as among elites. It resonated deeply with arguments in favor of states' rights that fit well with anti-tax and anti-Big Government strands of conservatism, as well as invocations of property rights and taxpayers' rights that

35. Findings of Fact and Conclusions of Law; Expert Testimony; Crawford v. Los Angeles Unified School District, UCLA Special Collections. Between 1960 and 1970, the Hispanic population of Los Angeles grew exponentially, largely as a result of the Immigration and Nationality Act of 1965 (Ethington, Frey, and Myers 2001). 
could justify protection of one's neighborhood and way of life without seeing oneself in racist terms. Indeed, it could appeal to a broader swath of voters who identified as centrist or even liberal but wanted to preserve certain prerogatives for their families and communities. These narratives about "freedom of choice," meritocratic individualism, and religious freedom have taken on a life of their own, beyond their origins in battles over racial integration-but they remain grounded in race, in their effects as well as their inspiration.

Because of the broad appeal of colorblind arguments, the southern California story is particularly pertinent. In stories about race in the United States, California often represents multiculturalism and racial equity - a post-racial future rather than the black-and-white past of the South or the old urban North. Yet many aspects of the Los Angeles story echo developments in other parts of the country-and in certain ways, Los Angeles was a leader in developing race-neutral arguments against integration and beating back civil rights efforts with legal victories and relatively little violence.

Several scholars have drawn the connection between the southern backlash to civil rights in the 1960s and the national embrace of the "free market" in the 1980s (Lowndes 2008; MacLean 2009, 2017), emphasizing the activities of elites: politicians, economists, and journalists who turned to privatization to preserve Jim Crow. Nancy MacLean explains that her elite focus is deliberate: "ordinary Americans ... were not in the driver's seat of this movement" (2009, 125). Her new blockbuster book, Democracy in Chains: The Deep History of the Radical Right's Stealth Plan for America, persuasively draws the connection between southern massive resistance to desegregation in the aftermath of Brown v. Board of Education and radical rightwing intellectuals' agenda of delegitimizing democratic government and giving free rein to the market. In her telling, the libertarian mastermind, economist James Buchanan, along with Milton Friedman, James Kilpatrick, and other like-minded academics and journalists, funded by billionaire Charles Koch, seized on the battle over Brown as an opportunity to further privatization and free-market ideals by destroying public education. This elite campaign had repercussions that reverberate into the present day, but the grassroots battles in Los Angeles suggest that the connections between opposition to integration on the one hand, and smallgovernment, libertarian ideas on the other did not begin and end at George Mason University, or even in the South as a whole. As early as the early 1960s, Californians were taking up arguments about freedom of association and freedom of choice to fight the integration of their neighborhoods and school systems. Although public-choice economists and other intellectual leaders undoubtedly influenced the conservative movement, an either/or approach is not necessary. When we turn to the legal arguments made for "freedom of association" and "freedom of choice," we see that anti-Big Government rhetoric as a weapon against civil rights came from below as well as from above-and from the West as well as from the South.

Today, the withdrawal of white Americans from public school systems, the segregated pattern of most of our major urban areas, and the continued de facto segregation of public life appear to be natural patterns of class stratification, yet they came about as the result of active choices. By the time a majority of the Supreme Court began declaring that the Constitution prohibited all racial classification, 
shifting the tide against metropolitan desegregation and affirmative action in the 1970s, grassroots political actors had been making race-neutral arguments against integration for many years. In fact, by the late 1970s, even self-identified racial liberals were making the connection between opposition to taxes and to desegregation. The real challenges to civil rights and integration, in Los Angeles as well as in Atlanta and Boston, were not demagogues and massive resisters such as Lester Maddox and Bull Connor, but the ordinary people who moved to the suburbs, took their children out of the public school system, rebelled against paying taxes for "their" public services, and demanded the right to "freedom of choice."

If that is the case, then perhaps the strategic questions legal historians have been asking about the civil rights movement are the wrong ones. Traditionally, legal scholars have asked whether social movements should or should not look to the courts, or frame their claims in legal and constitutional terms, and turn to the history of Brown to ask that question (Rosenberg 1992; Klarman 2004; Albiston and Leachman 2015). The new legal histories of civil rights have already taken us a great distance from that tired debate by showing us that at the grassroots, activists and lawyers had much more complicated relationships with the courts, and there was not an either/or relation between community organizing and litigating (Mack 2005, 2012; Goluboff 2007; Brown-Nagin 2011). We might also ask: If colorblind conservatism came from below as well as from above, what does that tell us about the possibilities of organizing for racial justice at the grass roots? What kinds of strategies are necessary for social change if the alternative constitutional claims of the civil rights movement are met by equally deeply felt constitutional claims from the Right? These are the questions we continue to struggle with today.

\section{REFERENCES}

Albiston, Catherine, and Gwendolyn Leachman. "Law as an Instrument of Social Change." In International Encyclopedia of the Social and Behavioral Sciences, 2nd ed., edited by J. Wright, 542-49. Amsterdam: Elsevier, 2015.

Barraclough, Laura R. Making the San Fernando Valley: Rural Landscapes, Urban Development, and White Privilege. Athens: University of Georgia Press, 2011.

Bartley, Numan. The Rise of Massive Resistance: Race and Politics in the South in the 1950s and 1960s. 2nd ed. Baton Rouge: Louisiana State University Press, 1999.

Bergholz, Richard. "Yorty Critical of Reagan on Housing Act." Los Angeles Times, September 28, 1967, A8.

Brown-Nagin, Tomiko. Courage to Dissent: Atlanta and the Long History of the Civil Rights Movement. Oxford: Oxford University Press, 2011.

Carter, Dan T., The Politics of Rage: George Wallace, the Origins of the New Conservatism, and the Transformation of American Politics. 2nd ed. Baton Rouge: Louisiana State University Press, 1995.

- From George Wallace to Newt Gingrich: Race in the Conservative Counterrevolution, 1963-1994. Baton Rouge: Louisiana State University Press, 1996.

Chalmers, David. Backfire: How the Ku Klux Klan Helped the Civil Rights Movement. Lanham, MD: Rowman \& Littlefield, 2003.

Chemerinsky, Erwin. The Conservative Assault on the Constitution. New York: Simon \& Schuster, 2010.

Crespino, Joseph. In Search of Another Country: Mississippi and the Conservative Counterrevolution. Princeton, NJ: Princeton University Press, 2007. 
. "Mississippi as Metaphor: Civil Rights, the South, and the Nation in the Historical Imagination." In The Myth of Southern Exceptionalism, edited by Matthew D. Lassiter and Joseph Crespino, 93-112. Oxford: Oxford University Press, 2010.

Didion, Joan. South and West: From a Notebook. New York: Alfred A. Knopf, 2017.

Dochuk, Darren. From Bible Belt to Sunbelt: Plain-Folk Religion, Grassroots Politics, and the Rise of Evangelical Conservatism. New York: W. W. Norton, 2011.

Driver, Justin. "Supremacies and the Southern Manifesto." Texas Law Review 92 (2014): 1053-1135.

Edsall, Thomas Byrne, and Mary D. Edsall. Chain Reaction: The Impact of Race, Rights, and Taxes on American Politics. New York: Norton, 1992.

Egerton, John. The Americanization of Dixie: The Southernization of America. New York: Harper's Magazine Press, 1974.

Egly, Paul. "Crawford v. Los Angeles Unified School District: An Unfulfilled Plea for Racial Equality." University of La Verne Law Review 31 (2010): 271-322.

Ethington, Philip J., William H. Frey, and Dowell Myers. "The Racial Resegregation of Los Angeles County, 1940-2000.” Public Research Report No. 2001-04, 2001. http://popdynamics. usc.edu/pdf/2001_Ethington-Frey-Myers_Racial-Resegregation.pdf.

Felter-Kantor, Max. "Fighting the Segregation Amendment: Black and Mexican American Responses to Proposition 14 in Los Angeles." In Black and Brown in Los Angeles: Beyond Conflict and Coalition, edited by Josh Kun and Laura Pulido, 143-75. Los Angeles: University of California Press, 2013.

Freund, David. Colored Property: State Policy and White Racial Politics in Suburban America. Chicago: University of Chicago Press, 2007.

Goluboff, Risa L. The Lost Promise of Civil Rights. Cambridge, MA: Harvard University Press, 2007.

Gotanda, Neil. "A Critique of 'Our Constitution Is Color-Blind.”' Stanford Law Review 44 (1999): $1-68$.

Gross, Ariela J. "The Caucasian Cloak': Mexican Americans and the Politics of Whiteness in the Twentieth-Century Southwest." Georgetown Law Journal 95 (2007): 337-92.

Haney Lopez, Ian F. "'A Nation of Minorities': Race, Ethnicity, and Reactionary Colorblindness." Stanford Law Review 59 (2007): 985-1063.

HoSang, Daniel Martinez. "The Triumph of Racial Liberalism, The Demise of Racial Justice." In Race and American Political Development, edited by Joseph Lowndes, Julie Novkov, and Dorian Warren, 288-311, New York: Routledge, 2008.

- Racial Propositions: Ballot Initiatives and the Making of Postwar California. Berkeley: University of California Press, 2010.

Hulburd, David. This Happened in Pasadena. London: Macmillan, 1951.

Hutchinson, Darren. "Racial Exhaustion." Washington University Law Review 86 (2009): 917-74.

Klarman, Michael. From Jim Crow to Civil Rights. Oxford: Oxford University Press, 2004.

Kruse, Kevin M. White Flight: Atlanta and the Making of Modern Conservatism. Princeton, NJ: Princeton University Press, 2005.

. "Beyond the Southern Cross: The National Origins of the Religious Right." In The Myth of Southern Exceptionalism, edited by Matthew D. Lassiter and Joseph Crespino, 286-307. Oxford: Oxford University Press, 2010.

Kull, Andrew. The Colorblind Constitution. Cambridge, MA: Harvard University Press, 1992.

Lands, LeeAnn. The Culture of Property: Race, Class, and Housing Landscapes in Atlanta, 1880-1950. Athens: University of Georgia Press, 2009.

Lassiter, Matthew D. Silent Majority: Suburban Politics in the Sunbelt South. Princeton, NJ: Princeton University Press, 2006.

. "De Facto/De Jure Segregation: The Long Shadow of a National Myth." In The Myth of Southern Exceptionalism, edited by Matthew D. Lassiter and Joseph Crespino, 25-48. Oxford: Oxford University Press, 2010.

Los Angeles Times. "Decision on Housing Initiative." Los Angeles Times, February 2, 1964, K6.

Lowndes, Joseph E. From the New Deal to the New Right: Race and the Southern Origins of Modern Conservatism. New Haven, CT: Yale University Press, 2008. 
Mack, Kenneth W. "Rethinking Civil Rights Lawyering and Politics in the Era Before Brown." Yale Law Journal 115 (2005): 256-354.

- Representing the Race: The Creation of the Civil Rights Lawyer. Cambridge, MA: Harvard University Press, 2012.

MacLean, Nancy. "Guardians of Privilege." In Debating the American Conservative Movement: 1945 to the Present, edited by Donald Critchlow and Nancy MacLean, 123-76. Lanham, MD: Rowman \& Littlefield, 2009.

. "Neo-Confederacy vs. The New Deal: The Regional Utopia of the Modern American Right." In The Myth of Southern Exceptionalism, edited by Matthew D. Lassiter and Joseph Crespino, 308-30. Oxford: Oxford University Press, 2010.

—. Democracy in Chains: The Deep History of the Radical Right's Stealth Plan for America. New York: Viking Books, 2017.

McGirr, Lisa. Suburban Warriors: The Origins of the New American Right. Princeton, NJ: Princeton University Press, 2001.

Murphy, Reg, and Hal Gulliver. The Southern Strategy. Ann Arbor: University of Michigan Press, 1971.

Nickerson, Michelle M. Mothers of Conservatism: Women and the Postwar Right. Princeton, NJ: Princeton University Press, 2012.

Nicolaides, Becky M. My Blue Heaven: Life and Politics in the Working-Class Suburbs of Los Angeles, 1920-1965. Chicago: University of Chicago Press, 2002.

Online Archive of California. Forty Years Defending the Constitution: Fred Okrand, interviewed by Michael Balter. Los Angeles: University of California, Los Angeles, 1984. http://www.oac. cdlib.org/view?docId=ft258003n2\&brnad=oac4\&doc.view=entire_text.

Phillips, Kevin. The Emerging Republican Majority. New Rochelle, NY: Arlington House, 1969.

Redlands Daily Facts. "Pasadena Schools Argue Before Court." Redlands Daily Facts, April 28, 1976, A12.

Rosenberg, Gerald. The Hollow Hope: Can Courts Bring About Social Change. Chicago: University of Chicago Press, 1992.

Sanchez, George J. "The History of Segregation in Los Angeles: A Report on Racial Discrimination and its Legacy." Unpublished paper. n.d. https://www.scribd.com/document/146802627/ The-History-of-Segregation-in-Los-Angeles.

Satter, Beryl. Family Properties: Race, Real Estate, and the Exploitation of Black Urban America. New York: Henry Holt, 2010.

Schmidt, Christopher W. "Brown and the Colorblind Constitution." Cornell Law Review 94 (2008): 203-38.

- "The Sit-Ins and the State Action Doctrine." William $\mathcal{E}$ Mary Bill of Rights Journal 18 (2010): 767-829.

- "Popular Constitutionalism on the Right: Lessons from the Tea Party." Denver University Law Review 88 (2011): 523-57.

—. "Defending the Right to Discriminate: The Libertarian Challenge to the Civil Rights Movement." In Signposts: New Directions in Southern Legal History, edited by Patricia Minter and Sally Hadden, 417-46. Athens: University of Georgia Press, 2013.

- "Divided by Law: The Sit-Ins and the Role of the Courts in the Civil Rights Movement." Law and History Review 33 (2015): 93-149.

Schulman, Bruce T., and Julian E. Zelizer, eds. Rightward Bound: Making America Conservative in the 1970s. Cambridge, MA: Harvard University Press, 2008.

Self, Robert O. American Babylon: Race and the Struggle for Postwar Oakland. Princeton, NJ: Princeton University Press, 2003.

Sides, Josh. L.A. City Limits: African American Los Angeles from the Great Depression to the Present. Berkeley: University of California Press, 2003.

Siegel, Reva B. "Dead or Alive: Originalism as Popular Constitutionalism in Heller." Harvard Law Review 122 (2008): 191-245.

Sokol, Jason. All Eyes Are Upon Us: Race and Politics from Boston to Brooklyn. New York: Basic Books, 2014. 
Southworth, Ann. Lawyers of the Right: Professionalizing the Conservative Coalition. Chicago: University of Chicago Press, 2008.

Sugrue, Thomas J. "Affirmative Action from Below: Civil Rights, the Building Trades, and the Politics of Racial Equality in the Urban North, 1945-1969." Journal of American History 91 (2004): 145-73.

- Sweet Land of Liberty: The Forgotten Struggle for Civil Rights in the North. New York: Random House, 2008.

Teles, Steven M. The Rise of the Conservative Legal Movement: The Battle for Control of the Law. Princeton, NJ: Princeton University Press, 2009.

Theoharis, Jeanne. "Hidden in Plain Sight: The Civil Rights Movement Outside the South." In The Myth of Southern Exceptionalism, edited by Matthew D. Lassiter and Joseph Crespino, 49-73. Oxford: Oxford University Press, 2010.

Time Magazine. "California: Proposition 14." Time, September 25, 1964. http://content.time.com/ time/magazine/article/0,9171,876158,00.html.

—.. "The Supreme Court: Saying No to Proposition 14." Time, June 9, 1967. http://www.time. com/time/magazine/article/0,9171,843888,00.html.

Torgerson, Dial. "Southland's Schools Hit by Taxpayer Rebellion." Los Angeles Times, March 5, 1967, H1.

US Commission on Civil Rights. A Generation Deprived: Los Angeles School Desegregation. CR 1.2: Ed 8/9. Washington, DC: Government Printing Office, 1977.

Walker, Anders. The Ghost of Jim Crow: How Southern Moderates Used Brown v. Board of Education to Stall Civil Rights. Oxford: Oxford University Press, 2009.

Walsh, Camille. "We Are Tax Paying Citizens': Race and the Right to Education." Paper presented at the American Society for Legal History, November 2011, Atlanta, GA.

- Racial Taxation: Whiteness, Segregated Schools, and Taxpayer Citizenship, 1869-1973. Chapel Hill: University of North Carolina Press, forthcoming.

Ward, Jason Morgan. Defending White Democracy: The Making of a Segregationist Movement and the Remaking of Racial Politics, 1936-1965. Chapel Hill: University of North Carolina Press, 2011.

Webb, Clive, ed. Massive Resistance: Southern Opposition to the Second Reconstruction. Oxford: Oxford University Press, 2005.

Williams, Daniel K. God's Own Party: The Making of the Christian Right. Oxford: Oxford University Press, 2010.

\section{CASES CITED}

Brown v. Board of Education, 347 U.S. 483 (1954).

Crawford v. Board of Education, 17 Cal.3d 280 (1976).

Hernandez v. Texas, 347 U.S. 475 (1954).

Jackson v. Pasadena, 59 Cal.2d 876; P.2d 878 (1963).

Plessy v. Ferguson, 163 U.S. 537 (1896).

Reitman v. Mulkey, 387 U.S. 369 (1967).

Shelley v. Kraemer, 334 U.S. 1 (1948).

Westminster Sch. Dist. v. Mendez, 161 F.2d 774 (9th Cir. 1947).

\section{STATUTE CITED}

Rumford Fair Housing Act, A.B. 1240 (1964). 